\title{
Multifunctional Role of the Whey Culture Medium in the Spray Drying Microencapsulation of Lactic Acid Bacteria
}

\author{
Stephania Aragón-Rojas', \\ María Ximena Quintanilla- \\ -Carvajal ${ }^{1 *}$ and Humberto \\ Hernández-Sánchez²
}

'Biosciences Doctoral Program, Faculty of Engineering, University of La Sabana, Common Campus Bridge, Km. 7 Bogota North Freeway, Chía, 140013 Cundinamarca, Colombia ${ }^{2}$ National School of Biological Sciences, National Polytechnic Institute, Av. Wilfrido Massieu esq. Cda. M. Stampa, UP Adolfo López Mateos, 07738 Ciudad de Mexico, Mexico

Received: 5 April 2017 Accepted: 20 June 2018

\section{(c) (i) (8)}

\section{SUMMARY}

This study aims to evaluate the multifunctional role of whey culture medium during the spray drying microencapsulation of Lactobacillus fermentum K73. Whey culture medium containing growing microorganisms served to hydrate different mixtures (gum arabic, maltodextrin and whey). We evaluated the use of these mixtures as carbon sources and their protective effects on simulated gastrointestinal conditions. The optimal mixture was spray-dried while varying the outlet temperature and atomizing pressure using a response surface design. These conditions served to evaluate microorganism survival, tolerance to gastrointestinal conditions in vitro, physicochemical properties, morphometric features and stability at 4,25 and $37{ }^{\circ} \mathrm{C}$. Lactobacillus fermentum K73 replicated in the carrier material. Bacterial change cycles were $(-1.97 \pm 0.16) \log \mathrm{CFU} / \mathrm{g}$ after the drying process and $(-0.61 \pm 0.08)$ and $(-0.23 \pm 0.00) \log \mathrm{CFU} / \mathrm{g}$ after exposure of the capsules to simulated gastric $\mathrm{pH}$ and bile salt content, respectively. The physicochemical properties and morphometric features were within the normal ranges for a powder product. The powder was stable at a storage temperature of $4{ }^{\circ} \mathrm{C}$. The spray drying of the whey culture medium with growing microorganisms using the optimized drying conditions was successful. This study demonstrates the use of whey culture medium as a component of carrier material or as the carrier material itself, as well as its protective effects during drying, under simulated gastrointestinal conditions, and at varied storage temperatures.

Key words: carrier material, Lactobacillus spp., microencapsulation, spray drying, whey

\section{INTRODUCTION}

The World Health Organization defines probiotics as live microorganisms, which when administered in adequate amounts, confer health benefits (1). It is recommended that the probiotic strain be isolated from a targeted population, as the microorganism can adapt to the consumers' nutrition and efficiently exert its health effects (2). Lactobacillus fermentum K73 is a strain isolated from suero costeño, a fermented food on the Colombian Atlantic coast, and in vitro studies characterized it as a potential probiotic and hypocholesterolemic agent (3). Therefore, including this microorganism in a food matrix has received interest for the development of functional foods for a specific targeted population.

One method of including the probiotic in a food matrix is microencapsulation (4). Microencapsulation is defined as the coating or entrapment of solid, liquid or gaseous materials within another material (5). The process involves four stages: (i) biomass production (6), (ii) mixture of the microorganism with carrier materials (7), (iii) drying (8), and (iv) inclusion in the food and/or shelf-life studies (9).

In the biomass production stage, the microorganism can adapt to thermal and osmotic stress conditions to tolerate the drying process (10). The microorganism and carrier material can be mixed by homogenization or pre-heating to dissolve the carrier material (11). Whey proteins $(12,13)$, maltodextrin (14) and gum arabic (15) have served as carrier materials. Whey is a byproduct of the dairy industry and is used as a component of culture medium (6) because it mainly contains lactose and soluble proteins (16). Although whey has important nutritional value, it is treated as dairy wastewater and has negative environmental effects 
(17). Therefore, using whey in an industrial process such as probiotic encapsulation at different levels (biomass production or carrier material) may provide a use for this dairy waste. In this study, we used whey culture medium with growing microorganisms as a carrier material for probiotic microencapsulation in one step. Maltodextrin is a maltooligosaccharide used to improve the survival of the probiotic after the spray drying process with industrially acceptable results in terms of physicochemical properties such as dissolution, hygroscopicity, moisture content and thermal properties (18). Gum arabic is an exudate gum from various Acacia species. It is a complex polysaccharide with a branched $\beta$-(1,3)-linked galactose backbone, which branches through the 1,6 positions, with arabinose, rhamnose and uronic acid (19). Its use as a dietary fibre enhances the growth of bifidobacteria in the gastrointestinal tract (20) and it is a good carrier material that links proteins to protect lactic acid bacteria during thermal processes (15).

The drying stage involves technologies such as spray drying (21), which reduces time and production costs. Studies have shown that the use of spray drying for probiotic microencapsulation with isolated whey proteins can maintain longer cell viability during the shelf life of the product (7), depending on the outlet temperature, residing time of the microorganism in the dryer chamber, and type of carrier material used (22).

After drying, the incorporation of microorganism into the final product ensures that the strains maintain their expected characteristics and number of viable cells $\left(10^{6}\right.$ to $10^{8}$ $\mathrm{CFU} / \mathrm{g}$ daily consumed product) during production and storage (weeks to months) and at the specified storage temperature (freezing, refrigeration, room temperature) (23). Finally, probiotics must survive the physiological conditions of the gastrointestinal tract, including the stomach $\mathrm{pH}$, enzymatic degradation, and presence of bile salts in the small intestine $(24,25)$.

The aim of this study is to evaluate the multifunctional role of whey culture medium in a complete microencapsulation process that guarantees the tolerance to gastrointestinal conditions in vitro of $L$. fermentum $\mathrm{K} 73$ through spray drying, and obtain a powdered product that can be part of a food matrix.

\section{MATERIALS AND METHODS}

\section{Materials}

De Man, Rogosa and Sharpe (MRS) broth and agar and peptone water were from Scharlau Microbiology (Scharlab, S.L., Barcelona, Spain). The yeast extract and phosphate buffer were from Oxoid Ltd. (Basingstoke, UK). Sweet whey was a product of a local company (Sopó, Colombia). The composition of the sweet whey (in \% by mass) was as follows: protein 11.67, lipids 2.0, carbohydrates 51.64, and ashes 10.9. The maltodextrin and gum arabic were from Shandong WNN Industrial Co., Ltd. (Weifang, PR China). Bile salt was from Sigma-Aldrich, Merck (St. Louis, MO, USA). Phosphorus pentoxide was from Merck (Darmstadt, Germany).

\section{Bacterial strain and culture conditions}

Lactobacillus fermentum K73 (GenBank KP784433.1) was stored at $-80^{\circ} \mathrm{C}$ with $20 \%$ sterilized glycerol as the cryoprotectant in MRS broth (26). The microorganism was grown in MRS broth for $24 \mathrm{~h}$ at $37^{\circ} \mathrm{C}$ under aerobic conditions before the experiment.

Biomass production was performed in a 1-litre bioreactor (BioFlo 110; New Brunswick Scientific Co., Inc., Edison, NJ, USA) with a workload of $800 \mathrm{~mL}$ at $37{ }^{\circ} \mathrm{C}$ and agitation at $3354 \times g$ for $10 \mathrm{~h}$. The culture medium contained $8 \%$ sweet whey and $0.22 \%$ yeast extract, and was adjusted to $\mathrm{pH}=5.5$ and sterilized at $121{ }^{\circ} \mathrm{C}$ for $15 \mathrm{~min}$. Lactobacillus fermentum K73 was inoculated at $10 \%$ (by volume). Cells were counted following fermentation, as described below.

\section{Preparation of the carrier material}

All suspensions used in the model (Table 1) were prepared at a final mass fraction of $40 \%$ soluble solids (27). The culture medium containing growing microorganisms (10 $\mathrm{h}$ of incubation) was used to hydrate each mixture used in the experimental design (Table 1). The mixtures were homogenized using a magnetic stirrer (1.8K; BT Lab Systems, Geno Technology, Inc, St. Louis, MO, USA) for $30 \mathrm{~min}$ at 130 rpm, and the initial cell counts were determinated. Next, the mixtures were incubated for $24 \mathrm{~h}$ at $(37 \pm 2){ }^{\circ} \mathrm{C}$. After incubation, cells were counted, and the bacterial change cycles under simulated gastrointestinal conditions (acid $\mathrm{pH}$ and bile salts) were evaluated. All experiments were performed in triplicate. The final cell count after homogenization was (10.29 \pm 0.18$) \log$ CFU/mL.

\section{Experimental design to select the carrier material}

The optimal mixture experimental design for obtaining the proportion of carrier material that improves bacterial survival under simulated gastrointestinal conditions was determined using Design Expert v. 8.0.7.1 (28). The design examined 12 mixtures (runs), with mixtures 2, 3, 9, 10 and 15 using one repetition (runs 16, 8, 14, 13 and 17, respectively) (Table 1), thus evaluating total of 17 runs. Maltodextrin, gum arabic and sweet whey were selected as carrier materials $(4,22,29)$. The bacterial change cycles after incubation (log $\mathrm{CFU} / \mathrm{mL}$ ) with the mixture proposed by the design and after simulated gastrointestinal conditions $(\log \mathrm{CFU} / \mathrm{mL})$ were the response variables.

The selected optimal mixture enabled the microorganisms to tolerate the simulated gastrointestinal conditions and showed a desirability equal or close to 1 (30). The criterion of desirability is a general approach in which the value of each response variable is transformed to a measurement ranging from $0-1$; values close to 1 represent maximization processes, while values close to 0 represent minimization processes $(30,31)$. 
Table 1. Optimization of mixture design to select the carrier material

\begin{tabular}{|c|c|c|c|c|c|c|}
\hline \multirow{3}{*}{ Run } & \multicolumn{3}{|c|}{ Factor } & \multicolumn{3}{|c|}{ Response variable: bacterial change cycle } \\
\hline & \multicolumn{3}{|c|}{$w($ material $) / \%$} & \multicolumn{3}{|c|}{$N /(\log C F U / m L)$} \\
\hline & Maltodextrin & Gum arabic & Whey & After mixing & Gastric pH & Bile salt \\
\hline 1 & 0.5 & 0.5 & 0 & $2.25 \pm 0.01$ & $-0.25 \pm 0.02$ & $0.16 \pm 0.05$ \\
\hline 2 & 0 & 0 & 1 & $1.21 \pm 0.02$ & $-1.31 \pm 0.02$ & $0.92 \pm 0.01$ \\
\hline 3 & 0 & 0.5 & 0.5 & $2.29 \pm 0.02$ & $-0.98 \pm 0.08$ & $1.09 \pm 0.12$ \\
\hline 4 & 0.42 & 0.42 & 0.17 & $0.39 \pm 0.09$ & $-0.59 \pm 0.10$ & $0.35 \pm 0.03$ \\
\hline 5 & 0.17 & 0.67 & 0.17 & $0.18 \pm 0.10$ & $-0.67 \pm 0.01$ & $0.61 \pm 0.02$ \\
\hline 6 & 0.67 & 0.17 & 0.17 & $1.58 \pm 0.11$ & $-0.56 \pm 0.04$ & $0.14 \pm 0.04$ \\
\hline 7 & 0.17 & 0.17 & 0.67 & $1.66 \pm 0.15$ & $-0.87 \pm 0.11$ & $0.79 \pm 0.02$ \\
\hline 8 & 0 & 0.5 & 0.5 & $2.15 \pm 0.01$ & $-0.93 \pm 0.07$ & $1.08 \pm 0.08$ \\
\hline 9 & 0.5 & 0 & 0.5 & $0.43 \pm 0.06$ & $-0.16 \pm 0.02$ & $0.02 \pm 0.00$ \\
\hline 10 & 1 & 0 & 0 & $2.68 \pm 0.05$ & $-1.05 \pm 0.02$ & $-0.05 \pm 0.09$ \\
\hline 11 & 0.42 & 0.17 & 0.42 & $0.47 \pm 0.06$ & $-0.64 \pm 0.12$ & $0.31 \pm 0.01$ \\
\hline 12 & 0.33 & 0.33 & 0.33 & $0.59 \pm 0.03$ & $-0.68 \pm 0.06$ & $0.22 \pm 0.06$ \\
\hline 13 & 1 & 0 & 0 & $2.71 \pm 0.14$ & $-1.05 \pm 0.04$ & $-0.02 \pm 0.00$ \\
\hline 14 & 0.5 & 0 & 0.5 & $0.48 \pm 0.01$ & $-0.16 \pm 0.02$ & $0.08 \pm 0.00$ \\
\hline 15 & 0 & 1 & 0 & $2.28 \pm 0.17$ & $-0.67 \pm 0.04$ & $0.58 \pm 0.02$ \\
\hline 16 & 0 & 0 & 1 & $1.18 \pm 0.07$ & $-1.25 \pm 0.03$ & $0.91 \pm 0.01$ \\
\hline 17 & 0 & 1 & 0 & $2.29 \pm 0.05$ & $-0.72 \pm 0.01$ & $0.42 \pm 0.04$ \\
\hline$p$-value & & & & 0.1772 & $<0.0001$ & $<0.0001$ \\
\hline
\end{tabular}

Results are expressed as mean value \pm standard deviation

\section{Drying process}

For the experimental design of the drying, two factors

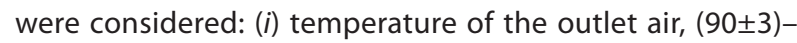
$(110 \pm 3)^{\circ} \mathrm{C}$, which was controlled by regulating the inlet flow, and (ii) atomizing air pressure, 0.08-0.15 MPa. The inlet air temperature for each run varied between 190 and $200^{\circ} \mathrm{C}$. The optimal mixture was a feed containing $40 \%$ total solids in the pilot-scale spray-dryer (GEA Process Engineering, Mobile Minor ${ }^{\mathrm{TM}}$, GEA Niro, Düsseldorf, Germany) for drying. The equipment was operated with a pneumatic co-current two-fluid nozzle as atomizer system (diameter of $1 \mathrm{~mm}$ ) with an evaporation capacity of $5 \mathrm{~L} / \mathrm{h}$. The response variables to be evaluated were: bacterial change cycles after drying (log CFU/g), bacterial change cycles (log CFU/g) after exposure of the capsules to simulated gastrointestinal conditions (acid pH and bile salts), physicochemical properties, and some morphometric features. The design included 12 runs with five replicates (run $1=16$, run $4=9$, run $7=13$, and run $8=10=14$ ) (Table 2). Analysis of variance (ANOVA), the adjusted determination coefficients, and contour plot generation were performed using Design Expert v. 8.0.7.1 (28). The conditions that maximized the survival of $L$. fermentum $\mathrm{K} 73$ after drying and minimized the effects on cell viability after exposure to simulated gastrointestinal tract conditions, with a desirability equal or close to 1 , were selected. The culture medium with growing microorganisms was dried under the optimized spray drying conditions to evaluate its function as carrier during spray drying. Cells were counted before and after drying and the results are in Table 2.

\section{Cell count}

The cell count of $L$. fermentum $\mathrm{K} 73$ in all proposed experiments was determined by plate counting in MRS agar after cultivation at $(37 \pm 2)^{\circ} \mathrm{C}$ for $24 \mathrm{~h}$ under aerobic conditions (32). Serial 1:9 dilutions in peptone water $(0.1 \%)$ were prepared. To count encapsulated cells, the capsule was dissolved (29). First, $0.1 \mathrm{~g}$ of powder was added to $9.9 \mathrm{~mL}$ sterile phosphate buffer $(0.1 \mathrm{M}, \mathrm{pH}=7.0)$ and then the capsule was hydrated for $15 \mathrm{~min}$ followed by vortexing for $10 \mathrm{~min}$. The bacterial change cycles were determined as:

Bacterial change cycle $=N_{\text {final }} /(\log C F U / m L$ or g) -

$$
-N_{\text {initial }} /(\log C F U / m L \text { or } g)
$$

Thus, the bacterial change cycles could show positive or negative values.

\section{Tolerance to simulated gastrointestinal conditions in vitro}

The simulated gastrointestinal conditions were prepared using MRS broth with some modifications. The MRS broth was adjusted to $\mathrm{pH}=2.0$ with $6 \mathrm{M} \mathrm{HCl}$ (33) to evaluate the tolerance to gastric $\mathrm{pH}$. The resistance to bile salt was evaluated by supplementing the media with $0.3 \%$ bile salt $(34,35)$. Both experiments were conducted by inoculating $100 \mu \mathrm{L}$ of the culture medium or mixture or $0.1 \mathrm{~g}$ of powder in modified MRS broth for $2 \mathrm{~h}$ at $37^{\circ} \mathrm{C}$. The initial and final cell counts were considered to determine the cell viability and bacterial change cycles. 


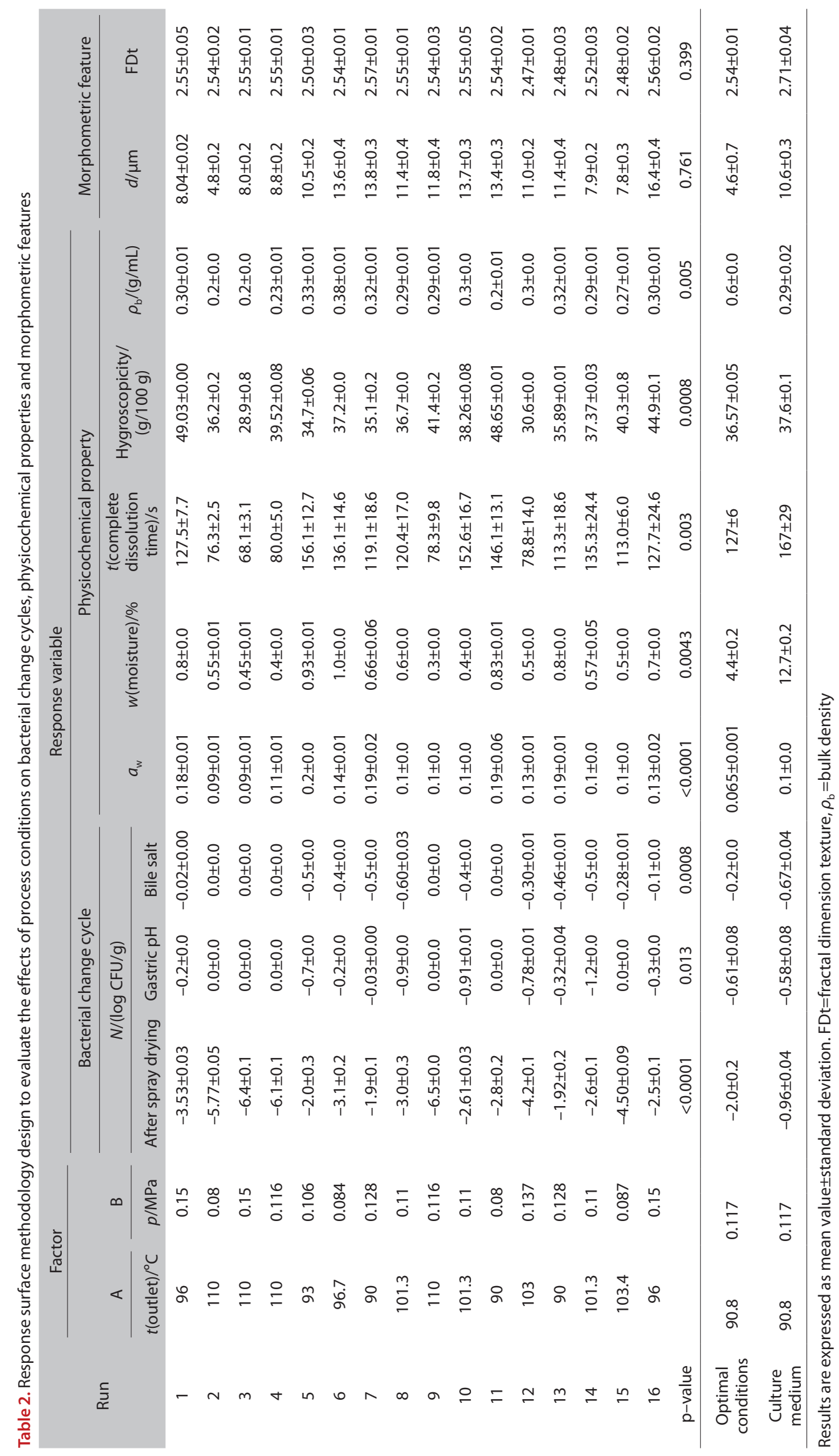




\section{Physicochemical parameters}

The powders obtained by spray drying were characterized according to their water activity $\left(a_{\mathrm{w}}\right)\left(\right.$ AquaLab ${ }^{\circledR}$, Model Series 4; Decagon Devices, Inc., Pullman, WA, USA), moisture (36), solubility $(37,38)$, hygroscopicity (37), and bulk density (39). All analyses were performed in triplicate.

\section{Scanning electron microscopy}

The morphology of the culture medium powder and the powder obtained under optimal conditions were observable by scanning electron microscopy (SEM, Phenom G2 Pro; Eindhoven, the Netherlands). Powders were dried in phosphorus pentoxide for 2 days and fixed on carbon tape (Ted 57; Ted Pella, Inc., Redding, CA, USA). SEM was conducted at an accelerating voltage of $10 \mathrm{kV}$ at $500 \times$ and $1500 \times$ magnification.

\section{Morphometric features}

The morphometric features were determined using the SEM images at a 500x and 1500x magnification (40). The 500x images were converted to grey scale with brightness values between 0 and 106 and saved as bitmap files (41). These files were then converted to binary images (black and white) using ImageJ v. 1.34 (42). The tool "Analyze particles" from ImageJ was used to calculate the particle area, this value served to estimate the mean diameter $(d / \mu \mathrm{m})$ of the particle.

The shifting differential box-counting method (SDBC plugin for the ImageJ software) was used to determine the fractal dimension texture (FDt). The $1500 \times$ magnification images were converted to bitmap files and cropped to obtain a square area of $22.86 \mu \mathrm{m} \times 18.29 \mu \mathrm{m}$. The FDt was calculated using this file (40).

\section{Shelf life}

Culture medium and powder obtained under optimal conditions were packed into Flex Up metallic bags (140 $\mu \mathrm{m}$; Alico SA, Bucaramanga, Colombia). The bags were vacuum-closed (0.0009 MPa, C200; Multivac, Barcelona, Spain) and stored at 4,25 and $37^{\circ} \mathrm{C}$ for 36 days (43). Cell count and water activity in the bag content were determined every 5 days.

The plot of relative viability ( $\log N_{\mathrm{t}} / N_{0}$ ) versus storage time was fitted to a first order equation (44):

$$
\log \left(N_{\mathrm{t}} / N_{0}\right)=k_{\mathrm{m}} \cdot t
$$

where $N_{\mathrm{t}}$ is the total viability of bacteria at time $t$ (day) during storage, $N_{0}$ is the viability of bacteria at time zero, and $k_{\mathrm{m}}$ is the cellular viability loss specific rate $\left(\right.$ day $\left.^{-1}\right)$ at the three evaluated temperatures.

The Napierian logarithm of the moisture content and water activity $\left(a_{\mathrm{w}}\right)$ values were plotted versus storage time. The values were fitted to a linear model:

$$
\ln \left(w \text { or } a_{w}\right)=A+k_{w \text { or } a_{w}} \cdot t
$$

where $\ln (w)$ is the Napierian logarithm of moisture content, $\ln \left(a_{\mathrm{w}}\right)$ is the Napierian logarithm of water activity, $k_{\mathrm{x}}$ is the constant of moisture content change rate, $k_{w}$ is the constant of water activity change rate, $A$ is the intercept of the curve and $t$ is time of storage. The effect of storage temperature on $k_{\mathrm{m}}$ was fitted to the Arrhenius equation (45):

$$
\ln (k)=\ln \left(k_{\mathrm{m}}\right)-\left(E_{\mathrm{a}} / R\right) \cdot\left(1 / T_{\text {ref }}\right)
$$

where $T_{\text {ref }}$ is the storage temperature, $E_{\mathrm{a}}$ is the activation energy $(\mathrm{J} / \mathrm{mol}), R$ is the universal gas constant $(\mathrm{J} /(\mathrm{mol} \cdot \mathrm{K}))$ and $k_{\mathrm{m}}$ is the cellular viability loss specific rate $\left(\right.$ day $\left.^{-1}\right)$.

The values from Eq. 3 were used in Eq. 4 to predict the storage duration under the three study temperatures (45):

$$
t(\text { storage })=\left[\left(\ln \left(E_{\mathrm{a}}\right)-\ln (N(\text { bacteria }))\right] /\left[\exp \left(A_{\mathrm{a}}+k_{\mathrm{y}} / T_{\text {ref }}\right)\right] \quad / 5 /\right.
$$

where $N$ (bacteria) $=10^{6} \mathrm{CFU} / \mathrm{g}$ is the amount of probiotic in a functional food before ingestion by the final consumer (46), and $A_{\mathrm{a}}$ is the intercept of the curve $\ln \left(k_{\mathrm{m}}\right)$ versus $\left(1 / T_{\text {ref }}\right)\left(\mathrm{R}^{2}=\right.$ 0.965 for culture medium powder curve and $R^{2}=0.981$ for optimal condition powder curve).

\section{RESULTS AND DISCUSSION}

The selection of the culture medium plays an important role in maintaining the viability of probiotics during microencapsulation (47). Therefore, we proposed using sweet whey culture medium because it: (i) can be added to the food matrix (16), (ii) contains the probiotic and is part of the carrier material (48), and (iii) can be dried with the growing microorganism directly (49), thus, the microorganism does not require downstream processing that increases the production costs and may affect the probiotic viability (50). Besides, this culture medium has multifunctional roles during microencapsulation.

\section{Selection of carrier material}

One stage of probiotic microencapsulation is mixing the microorganism with the carrier material (47). In this study, the microorganism grew on an average $(1.25 \pm 0.03) \mathrm{log} C F U / \mathrm{mL}$ in all suspensions, and thus, the model was not significant ( $p$-value $=0.1772$, Table 1) for the response variable bacterial change cycles after the mixting. This may be because lactose in the whey from the carrier material was used as a carbon source (6) and small peptides or amino acids in the medium are delivered to the culture medium as metabolizable substrates (51). Liong and Shah (52) used maltodextrin in culture medium. They found that Lactobacillus casei ASCC 292 metabolized maltodextrin by fermentation, which enhanced the production of propionic acid. Thus, maltodextrin can be used as a carbon source for L. fermentum K73 in the carrier material. Using maltodextrin in the powder may have advantageous effects on taste according to in vivo assays. Olano-Martin et al. (53) used a three-stage continuous culture cascade system that simulates different regions of the large intestine containing human gut microorganisms. They reported that after incubation with maltodextrin as a carbohydrate source, the population of bifidobacteria and lactobacilli increased. Therefore, maltodextrin may have probiotic effects. Gum arabic is a dietary fibre that improves the growth 
of bifidobacteria $(20,54)$ and Enterococcus faecium NCIMB 30183 (20), but does not have growth-stimulating effects on $L$. paracasei NFBC338 (19). In contrast to the results of Desmond et al. (19), L. fermentum K73 grew for 2.28 and 2.29 cycles (runs 15 and 17 respectively, Table 1). This suggests that the microorganism uses gum arabic and should be further examined.

Additionally, the mass fraction of maltodextrin, gum arabic, and sweet whey influenced the survival of $L$. fermentum K73 under simulated gastrointestinal conditions. The response of bacterial change cycles to gastric $\mathrm{pH}$ conditions was fitted to a cubic mixture model, and the response of bacterial change cycles to the presence of bile salt was fitted to a quadratic model (Table 3).

The models were highly significant $(p<0.0001)$ with a non-significant lack of fit ( $p=0.2729$ and 0.1283 , respectively).
The regression coefficients and significance test results are shown in Table 3. The combination of components maltodextrin+gum arabic, maltodextrin+sweet whey, and the third-order interaction between the compounds had a significant effect $(p<0.0001)$ on the tolerance of the microorganism to an in vitro simulated gastric $\mathrm{pH}$ environment. Additionally, the interaction between maltodextrin+whey $(\mathrm{p}=0.0001)$ and gum arabic+whey $(p=0.0003$ ) influenced the survival of $L$. fermentum K73 in the medium simulating the concentration of bile salt in the small intestine. The regression equations of the model with the interactions between maltodextrin, gum arabic and whey (C) are shown in Table 3.

Fig. 1 shows the simplex plots for the response variables evaluated under in vitro simulation of gastrointestinal conditions. Fig. 1a shows that the lowest difference between the

Table 3. Analysis of variance (ANOVA) of mixture design and regression equations for bacterial change cycles under gastric $\mathrm{pH}$ and bile salt conditions

\begin{tabular}{|c|c|c|c|c|c|c|c|c|c|c|}
\hline \multirow[b]{3}{*}{ Source } & \multicolumn{10}{|c|}{ Bacterial change cycle } \\
\hline & \multicolumn{5}{|c|}{ Gastric pH } & \multicolumn{5}{|c|}{ Bile salt } \\
\hline & $\begin{array}{l}\text { Sum of } \\
\text { squares }\end{array}$ & Df & $\begin{array}{l}\text { Mean } \\
\text { square }\end{array}$ & F-value & p-value & $\begin{array}{l}\text { Sum of } \\
\text { squares }\end{array}$ & Df & $\begin{array}{l}\text { Mean } \\
\text { square }\end{array}$ & F-value & $p$-value \\
\hline Model & 1.86 & 6 & 0.31 & 246.54 & $<0.0001^{*}$ & 2.36 & 5 & 0.47 & 60.03 & $<0.0001^{*}$ \\
\hline Linear mixture & 0.27 & 2 & 0.14 & 109.09 & $<0.0001^{*}$ & 1.86 & 2 & 0.93 & 118.13 & $<0.0001^{*}$ \\
\hline$A B$ & 0.34 & 1 & 0.34 & 272.17 & $<0.0001^{*}$ & 0.01 & 1 & 0.01 & 0.90 & 0.36 \\
\hline$A C$ & 1.35 & 1 & 1.35 & 1075.74 & $<0.0001^{*}$ & 0.26 & 1 & 0.26 & 33.19 & $0.0001^{*}$ \\
\hline $\mathrm{BC}$ & 0.00 & 1 & 0.00 & 1.07 & 0.3245 & 0.21 & 1 & 0.21 & 26.60 & $0.0003^{*}$ \\
\hline$A B C$ & 0.24 & 1 & 0.24 & 186.77 & $<0.0001^{*}$ & & & & & \\
\hline Residual & 0.01 & 10 & 0.00 & & & 0.09 & 11 & 0.01 & & \\
\hline Lack of fit & 0.01 & 5.00 & 0.00 & 1.77 & 0.27 & 0.07 & 6.00 & 0.01 & 2.94 & 0.13 \\
\hline Pure error & 0.00 & 5.00 & 0.00 & & & 0.02 & 5.00 & 0.00 & & \\
\hline Corr. total & 1.88 & 16.00 & & & & 2.44 & 16.00 & & & \\
\hline $\mathrm{R}^{2}$ & 0.99 & & & & & 0.96 & & & & \\
\hline $\begin{array}{l}\text { Final equation } \\
\text { in terms of real } \\
\text { components }\end{array}$ & \multicolumn{5}{|c|}{$\begin{array}{c}N /(\log C F U / m L)=1.052 A+0.692 B+1.282 C- \\
-2.493 A B-3.965 A C+12.521 A B C\end{array}$} & \multicolumn{5}{|c|}{$\begin{array}{c}\mathrm{N} /(\log \mathrm{CFU} / \mathrm{mL})=0.006 \mathrm{~A}+0.504 \mathrm{~B}+0.935 \mathrm{C}- \\
-1.589 \mathrm{AC}+1.484 \mathrm{BC}\end{array}$} \\
\hline
\end{tabular}

$A=$ maltodextrin, $B=$ gum arabic, $C=$ whey; ${ }^{*}$ significant at $a=0.05$

a)

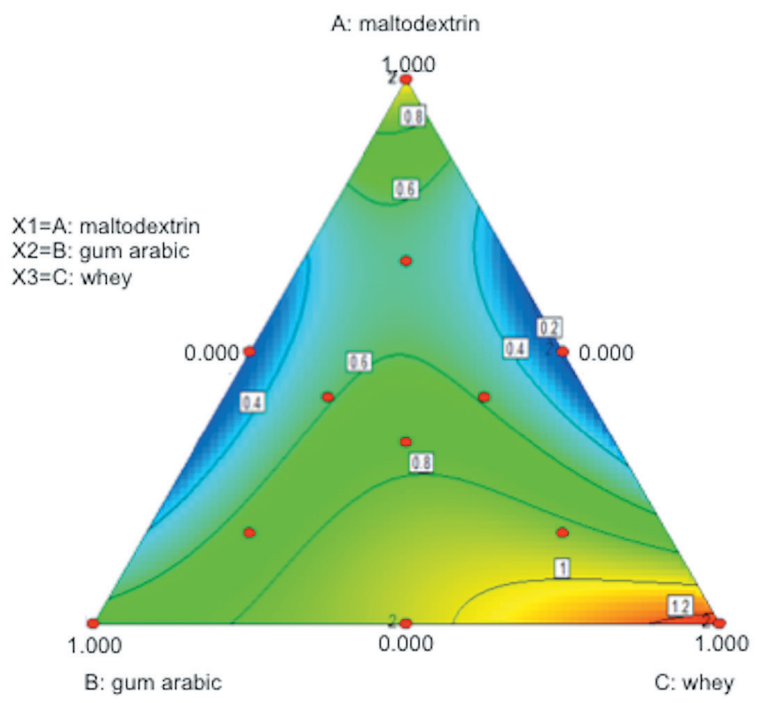

b)

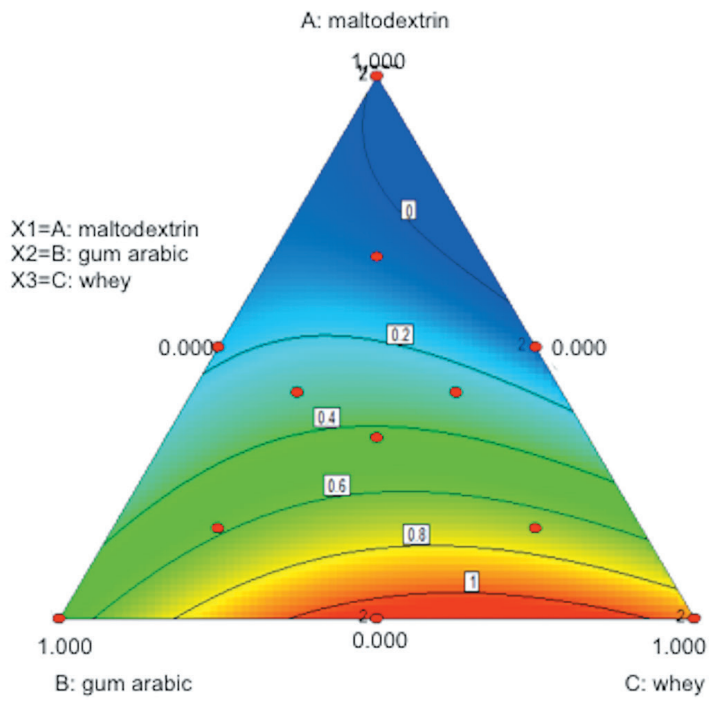

Fig. 1. Simplex plot of bacterial change cycles of Lactobacillus fermentum K73 after: a) gastric $\mathrm{pH}$ conditions, and b) bile salt conditions 
final and initial cell count under gastric $\mathrm{pH}$ conditions was observable in the binary mixtures of maltodextrin+whey and maltodextrin+gum arabic. However, when analyzing the estimated coefficients of the three factors (Table 3 ), the results showed that the maltodextrin and sweet whey helped the survival of the microorganism under gastric $\mathrm{pH}$ conditions. This effect was largely observed when estimating second-order effects found on the side of the simplex between vertices $A$ and C. Fig. $1 \mathrm{~b}$ shows, in apex $A$ of the simplex, the strong and positive effect of maltodextrin and whey on the microorganism under bile salt conditions, which agrees with the coefficient analysis and regression coefficient shown in Table 3.

The model showed that the interactions between maltodextrin and sweet whey had a protective effect on the microorganism under gastrointestinal conditions (after incubation in carrier material and during spray drying). This can be attributed to the abilities of maltodextrin and whey lactose to bind to polar residues of proteins and maintain the integrity of cell membranes (55). However, the mixture reconstituted with culture medium, which contains denatured whey following sterilization, exposes a higher number of functional groups that interact with the non-denatured whey and maltodextrin, forming a strong crosslink between the compounds. Its materials also interact with cell membrane components, generating a viscous layer on the microorganism and reducing the mobility of water across the membrane. This mixture protects the phospholipid of the cell membrane during spray drying (9) and prevents intracellular acidification by $\mathrm{HCl}$ and colic acid, which are a product of the hydrolysis of sodium taurocholate and sodium glycolate, and thus maintains the viability of microorganisms in the carrier material $(43,56)$.

Desirability analysis determined that $-0.19 \log$ CFU/mL indicated the decrease of the bacterial change cycles at gastric $\mathrm{pH}$; in the presence of bile salts, the increase in the cell count was $0.02 \log \mathrm{CFU} / \mathrm{mL}$, with corresponding mixture ratio of maltodextrin/whey 0.61:0.39 for a desirability of 0.97. The results were corroborated experimentally using the optimal mixture. The decrease in population at gastric $\mathrm{pH}$ was by $(-0.12 \pm 0.04) \log C F U / m L$, and the increase in population in the presence of bile salt was by $(0.15 \pm 0.05) \log C F U / m L$. These results largely agree with those of the model predictions. Thus, this mixture was used in the spray drying experiments.

\section{Spray drying}

After selecting the carrier material, the spray drying using the optimal mixture was conducted. The RSM design was performed to determine the drying conditions (outlet temperature and atomizing pressure) that improved the protective effect of the selected mixture.

ANOVA of the experimental design for the bacterial change cycles after drying showed significant results with $p<0.0001$ and a determination coefficient $R^{2}=0.95$. The linear effect of outlet temperature, quadratic effect of the outlet temperature and quadratic effect of atomizing pressure were significant within the model $(p \leq 0.05)$.
Fig. 2 shows the effects of outlet temperature and atomizing pressure on the capacity of the microorganism to tolerate the drying process and their influence on probiotic properties. Fig. 2a shows that viability decreased as the outlet temperature increased and atomizing pressure decreased. As outlet temperature increased, the microorganism viability decreased, which was related to cell damage caused by DNA and RNA denaturation, ribosome damage, cytoplasm dehydration and cell membrane damage. This depends on the speed at which heat and mass transfer occur from the inside to the outside of the cell $(36,47,57)$. This may explain the highest linear effect (F-val$\mathrm{ue}=149.04$ ) of the outlet temperature on the viability of $L$. fermentum K73 after drying. Furthermore, the low pressure decreased cell viability, possibly because the atomizing pressure directly affected capsule flexibility, causing more resistance of the carrier material mixture to the migration of water, both in the cell and the capsule itself (58).

a)

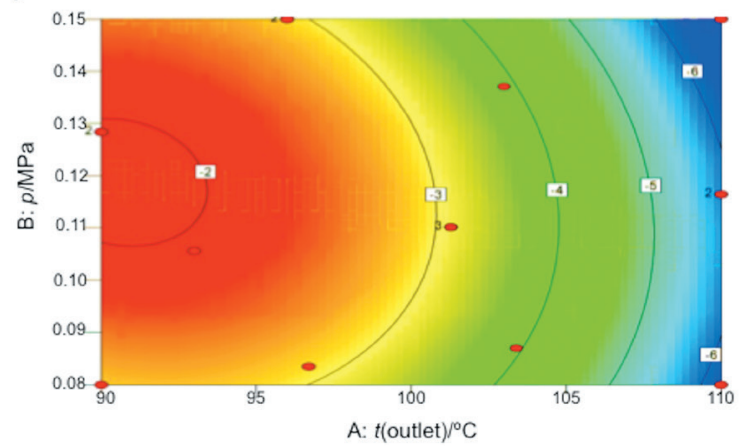

b)

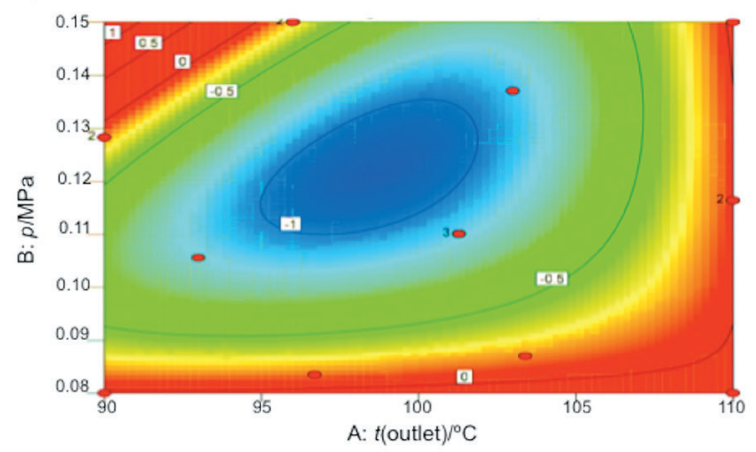

c)

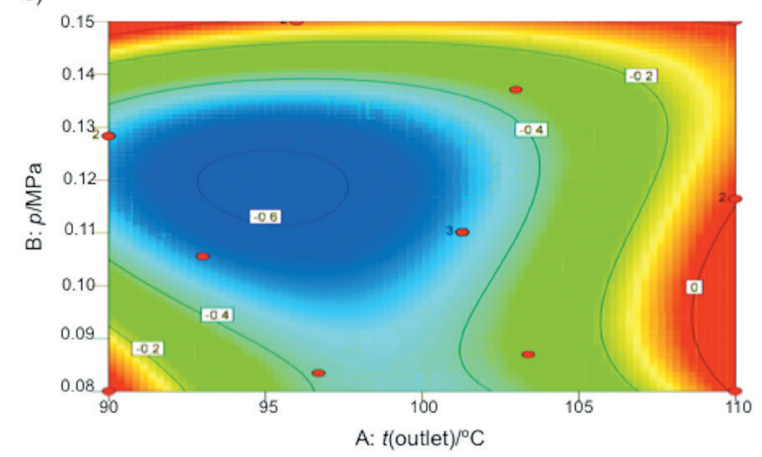

Fig. 2. Contour plots of bacterial change cycles $(N /(\log C F U / g))$ after: a) spray drying, b) gastric $\mathrm{pH}$ conditions after spray drying, and c) bile salt conditions after spray drying 
The results showed that under all drying conditions, the cell count decreased when the powder was exposed to simulated gastrointestinal conditions. The bacterial change cycles under gastric $\mathrm{pH}$ and bile salt conditions were fitted to cubic models with $p$-values of 0.013 and 0.0008 and $R^{2}=0.92$ and 0.97 , respectively. In both models, the quadratic effect of atomizing pressure $\left(F-\right.$ value $_{\text {gastric } p H \text { conditions }}=26.4, F-$ value $_{\text {bile salt }}$ conditions $=37.6$ ) was the most influential value on the capacity to tolerate gastrointestinal conditions, followed by the quadratic effect of outlet temperature ( $F$-value gastric $\mathrm{pH}$ conditions $=20.66$, $F_{-}$-value $e_{\text {bile salt conditions }}=29.52$ ). The three types of interaction between the outlet temperature and atomizing pressure influenced the tolerance to gastric $\mathrm{pH}$. In contrast, the outlet temperature and its interaction with the quadratic effect of atomizing pressure influenced the capacity of $L$. fermentum K73 to tolerate bile salt.

The contour diagram in Fig. $2 \mathrm{~b}$ shows that at an atomizing pressure between 0.13 and $0.15 \mathrm{MPa}$ and outlet temperature close to $90^{\circ} \mathrm{C}$, the microorganism was able to tolerate gastric $\mathrm{pH}$. In contrast, the contour diagram in Fig. $2 \mathrm{c}$ shows that at a pressure between 0.08 and $0.12 \mathrm{MPa}$ and outlet temperature of $110^{\circ} \mathrm{C}$ the probiotic was able to tolerate bile salt. This agrees with the coefficients and magnitudes expressed in the regression equations in Table 4. Therefore, after drying, the capsule protects the microorganism from the gastrointestinal conditions. The protection may be attributed to physicochemical properties, such as crosslinking between whey proteins and maltodextrin. The increased outlet temperature and atomizing pressure result in the formation of a compact powder, and thus, the microcapsule membrane does not facilitate diffusion of the substances (14) such as $\mathrm{HCl}$ or colic acid into the microcapsule, with the microcapsule acting as a physical barrier. Therefore, these conditions enhanced the survival of the microorganism under simulated gastrointestinal conditions, although the outlet temperature of $110^{\circ} \mathrm{C}$ injured the cell membrane, as described above.

The optimal conditions for spray drying were: atomizing pressure of $0.117 \mathrm{MPa}$, outlet temperature of $90.8^{\circ} \mathrm{C}$, and inlet temperature of $175^{\circ} \mathrm{C}$ (Table 2), with a desirability of 0.999 . The experimental data validated the model and showed a decrease of $(-2 \pm 0.2) \log$ CFU/g after drying or $(-0.61 \pm 0.08)$ log $\mathrm{CFU} / \mathrm{g}$ after exposure to in vitro conditions of gastric $\mathrm{pH}$, and decrease of $(-0.2 \pm 0.0) \log C F U / g$ after the addition of bile salt.

The culture medium was dried under optimal drying conditions and examined if it could act as a carrier material. Table 2 shows the bacterial changes after drying and after the exposure of the microcapsules to simulated gastrointestinal conditions in vitro when the culture medium was used as the carrier material. Compared with the powder obtained under optimal conditions, the culture medium powder showed the highest viability after drying $(-0.96 \pm 0.04$ $\log$ CFU/g) and under simulated gastrointestinal conditions (gastric pH: $(-0.58 \pm 0.08) \log C F U / g$, bile salt: $(-0.67 \pm 0.04) \log$ $\mathrm{CFU} / \mathrm{g})$. The low content of solids ( $8 \%$ ) in the culture medium form a feed liquid with low viscosity, which at the beginning of spraying in the drier may increase the retention time and expose the microorganism to a higher temperature in the drying chamber (59). However, this common interpretation contrasts the results of our study. The most likely explanation of the successful use of the culture medium as a carrier is as follows: the hydrophobic and sulfhydryl groups are exposed because whey proteins from the culture medium are denatured by sterilization, and these groups begin irreversible aggregation (60), and thus the culture medium is a heterogeneous feed liquid because agglomerates have dense and irregular structures (Fig. 3) (61). When the culture medium containing microorganisms was sprayed in the drier, the inlet and outlet temperature and atomizing pressure removed the water from the feed liquid (culture medium) and compacted the denatured whey aggregates, giving the microcapsules a rigid surface (62); however, the temperature in the drying chamber was not sufficient to evaporate the water ( $92 \%$ wet basis) and the core of the microcapsules had a high moisture content ((12.7 \pm 0.2$) \%$ wet basis, Table 2). Çabuk and Harsa (63) also reported this high moisture content of $>10 \%$ (wet basis), with high survival rates of L. acidophilus NRRL B-4495, and they concluded that it is not possible to establish a correlation only based on the moisture content. However, the capsules with high moisture content may create a microenvironment in which the microorganism can repair the damage to the cell membrane after spray drying. This hypothesis requires further analysis. Additionally, the whey proteins have a buffering effect at gastric $\mathrm{pH}$ to improve microorganism survival (64). This may cause low bacterial change cycles at acidic $\mathrm{pH}$.

\section{Final product}

The powder obtained under optimal drying conditions and culture medium powder (Table 2 ) were characterized based on the water activity $\left(a_{w}\right)$, humidity, solubility, hygroscopicity and bulk density. The $a_{\mathrm{w}}$ and moisture content were $0.09-0.19$ and $0.66-1.0 \%$, respectively (Table 2 ). The values of $a_{\mathrm{w}}$ were adjusted to a linear model, with $\mathrm{p}$-value $<0.0001$ and $\mathrm{R}^{2}=0.81$ (Table 5). The outlet temperature showed a statistically significant effect $(\mathrm{p}<0.0001)$ on $a_{\mathrm{w}}$. The moisture content was adjusted to a cubic model with $\mathrm{p}=0.0043$ and $\mathrm{R}^{2}=0.94$ (Table 5). The outlet temperature and cubic effect of the outlet temperature had the greatest influence on the moisture content in the microcapsules. Therefore, higher outlet $\left(110^{\circ} \mathrm{C}\right)$ and inlet temperature $\left(200^{\circ} \mathrm{C}\right)$ produced a powder with lower moisture content than under the other evaluated temperatures, thereby suggesting temperature to be the most important factor (14), which agrees with the results of the contour plot in Fig. 4. Figs. $4 \mathrm{a}$ and $4 \mathrm{~b}$ show that the lowest values of $a_{w}$ and moisture content were observed at $110^{\circ} \mathrm{C}$, which is consistent with the coefficients shown in the linear equation and regression equation (Table 5).

The solubility measurement of the powders was adjusted to a quadratic model (Table 5 ), as shown by ANOVA, with $p=0.003$ and $R^{2}=0.80$. The outlet temperature and its quadratic effect influenced the ability to reconstitute the powder. In 


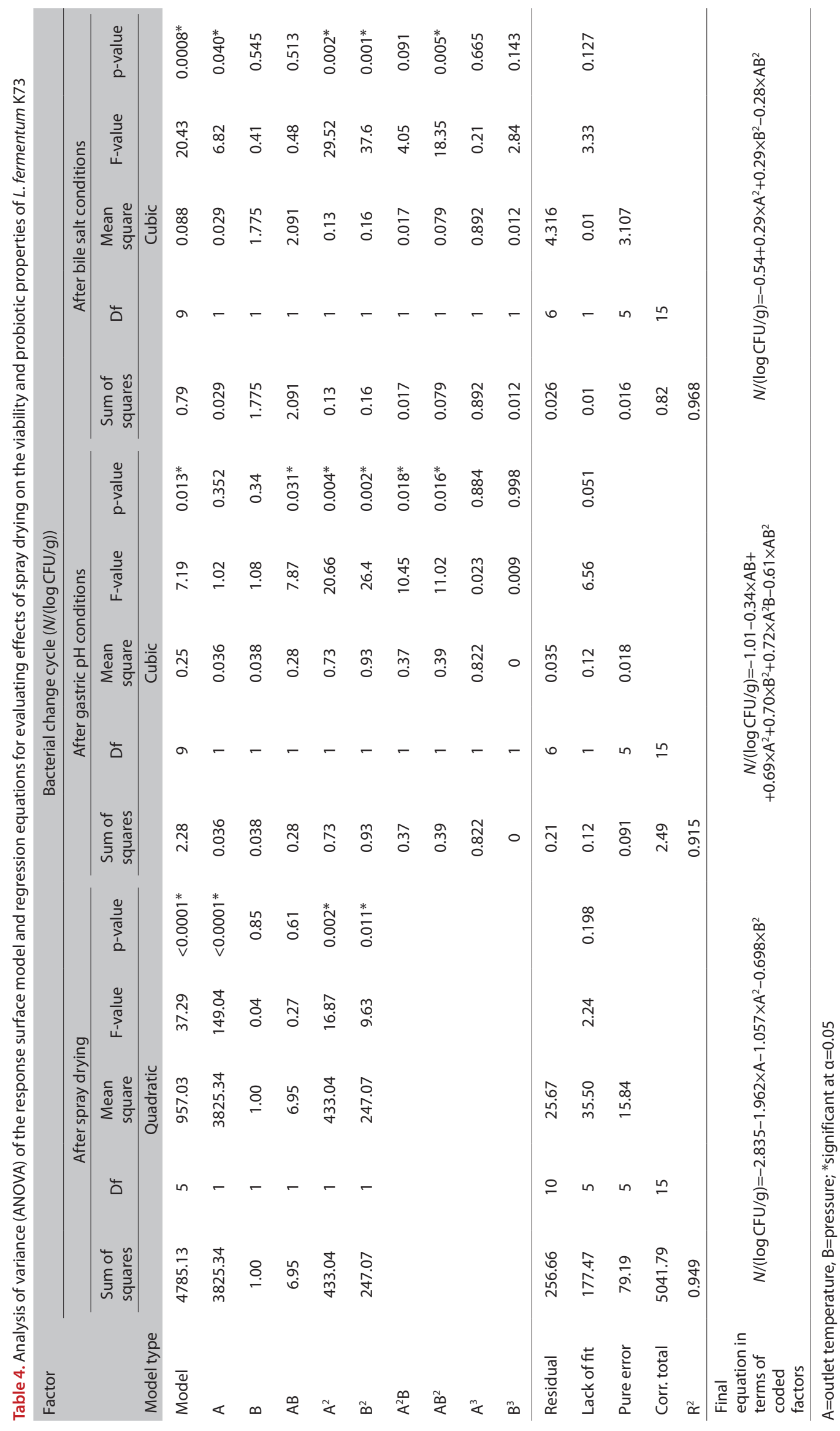




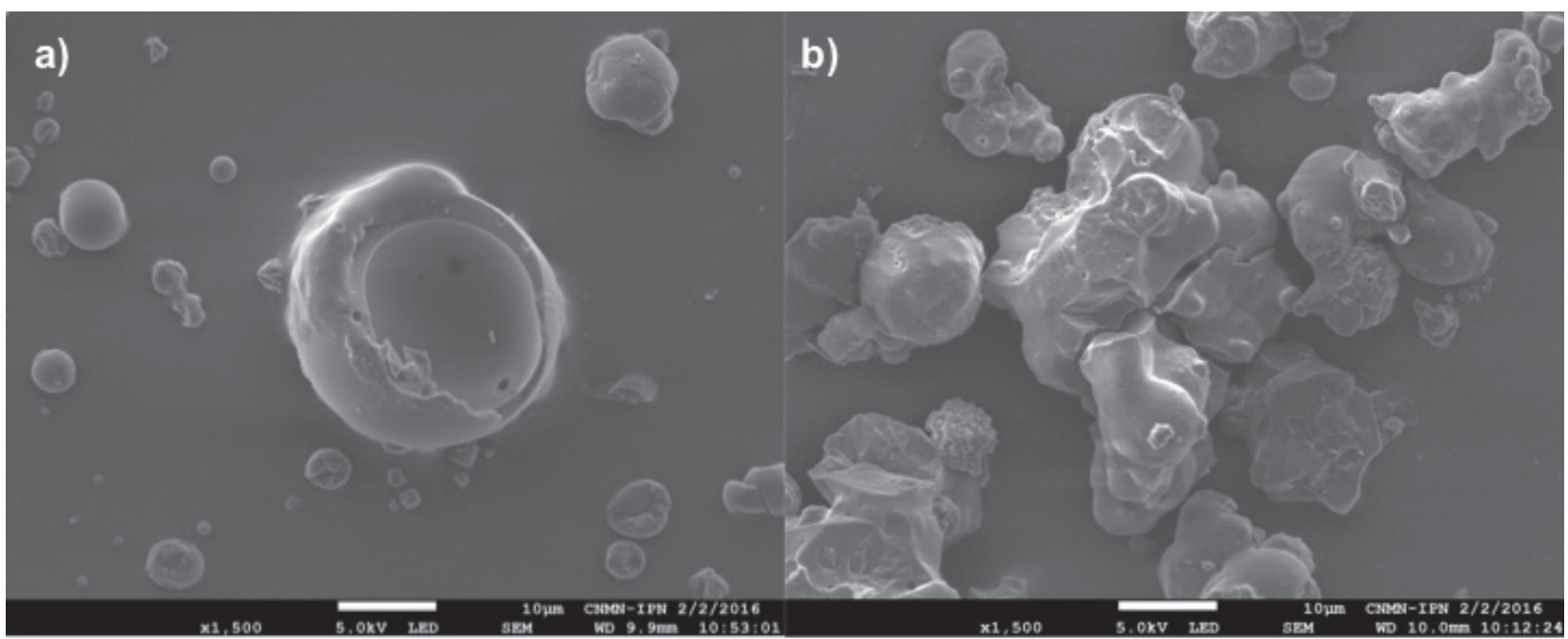

Fig. 3. Micrographs of: a) maltodextrin and whey mixture, and b) culture medium powder under optimal drying conditions. The magnification was $1500 x$

accordance with the regression coefficients, the longest time to solubilize the sample occurred at temperatures close to $90^{\circ} \mathrm{C}$ (Fig. 4c).

The hygroscopicity values were adjusted to a cubic model ( $p=0.0008$ ) with an $R^{2}=0.97$ (Table 5). The first-order interaction between the outlet temperature and atomizing pressure, quadratic effect of the outlet temperature and atomizing pressure, second-order interaction between the outlet temperature and atomizing pressure squared, and cubic effect of both factors were significant for the model. Fig. 4d shows that at temperatures of $105-110^{\circ} \mathrm{C}$, the hygroscopicity of the capsules increased. The optimal hygroscopicity for spray drying was $(15.6 \pm 0.5) \mathrm{g} / 100 \mathrm{~g}$.

The data obtained for bulk density were adjusted to a cubic model with $p=0.0050$ and $p<0.0001$ and $R^{2}=0.94$ and 0.99 , respectively. For both response variables, the quadratic and cubic effects of the outlet temperature showed significant effects $(p \leq 0.05)$ (Table 5$)$. The bulk density results showed that higher outlet and inlet temperatures decreased the density of powders (Fig. 4e) because of more rapid drying of the particle. This fixed the particle dimensions before most of the water content had evaporated, which agrees with the results of a previous study (65).

The final product of the spray drying under optimal conditions was characterized according to the physicochemical properties. In this study, we obtained an optimal product for the food industry. The moisture content and $a_{w}$ were $<4 \%$ and $<0.2$, respectively. The isosmotic conditions generated between the wall and cell membrane and the water monolayer that maintains the shape and structure of enzymes and proteins are maintained (66). In contrast, a low moisture content and $a_{\mathrm{w}}$ prevent the growth of the accompanying microorganisms in the powder, thereby extending its lifetime (67).

The time to complete the dissolution in water, including the time of $(126.99 \pm 5.92)$ s obtained from the dried powder under optimal conditions, was comparable to those reported by Fritzen-Freire et al. (37) and Pinto et al. (38), who suggested that during spray drying, the hydrophilic groups in lactose and whey proteins are more exposed. Moreover, the absence of fat on the surfaces of the particles makes the powder more hydrophilic, causing its water solubility to increase.

The hygroscopicity of the samples, including the microcapsules obtained under the optimal spray drying conditions, (15.6 \pm 0.5$) \mathrm{g} / 100 \mathrm{~g}$, was comparable to those of microcapsules containing 20-30\% maltodextrin, as reported by Tonon et al. (68), who attributed this property to the high concentration of maltodextrin, which has low hygroscopicity, confirming its effectiveness for use as a carrier material.

The physicochemical properties of the culture medium powder were compared with those of the powder obtained under optimal conditions. The time to complete dissolution of the culture medium powder ((166.66 \pm 29.2$) \mathrm{s})$ was higher than

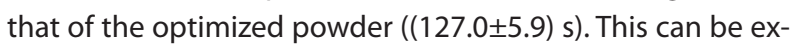
plained by the hydrophobic properties of the denatured whey proteins, which decrease microparticle solubility. The difference between the hygroscopicity of culture medium powder and that obtained under optimal conditions ((36.57 \pm 0.05$)$ and $(37.65 \pm 0.13) \mathrm{g} / 100 \mathrm{~g}$, respectively) was low. The hygroscopicity value of the culture medium powder is attributed to the greater number of hydrophobic amino acid residues from the denatured whey proteins, which affect water adsorption (37). The bulk density of the powder obtained under optimal conditions was $(0.55 \pm 0.00) \mathrm{g} / \mathrm{mL}$, whereas that of the culture medium powder was $(0.29 \pm 0.02) \mathrm{g} / \mathrm{mL}$. Felix et al. (14) reported that adding maltodextrin to the carrier material increased the final bulk density.

Finally, the microencapsulation process proposed in this study was performed using pilot-scale equipment. Performing this type of study using robust equipment would enable the development of microencapsulation processes easily adaptable to the food industry, without the need for large changes in the drying technology, preparation of the carrier material and preparation of the biomass acquisition process. 


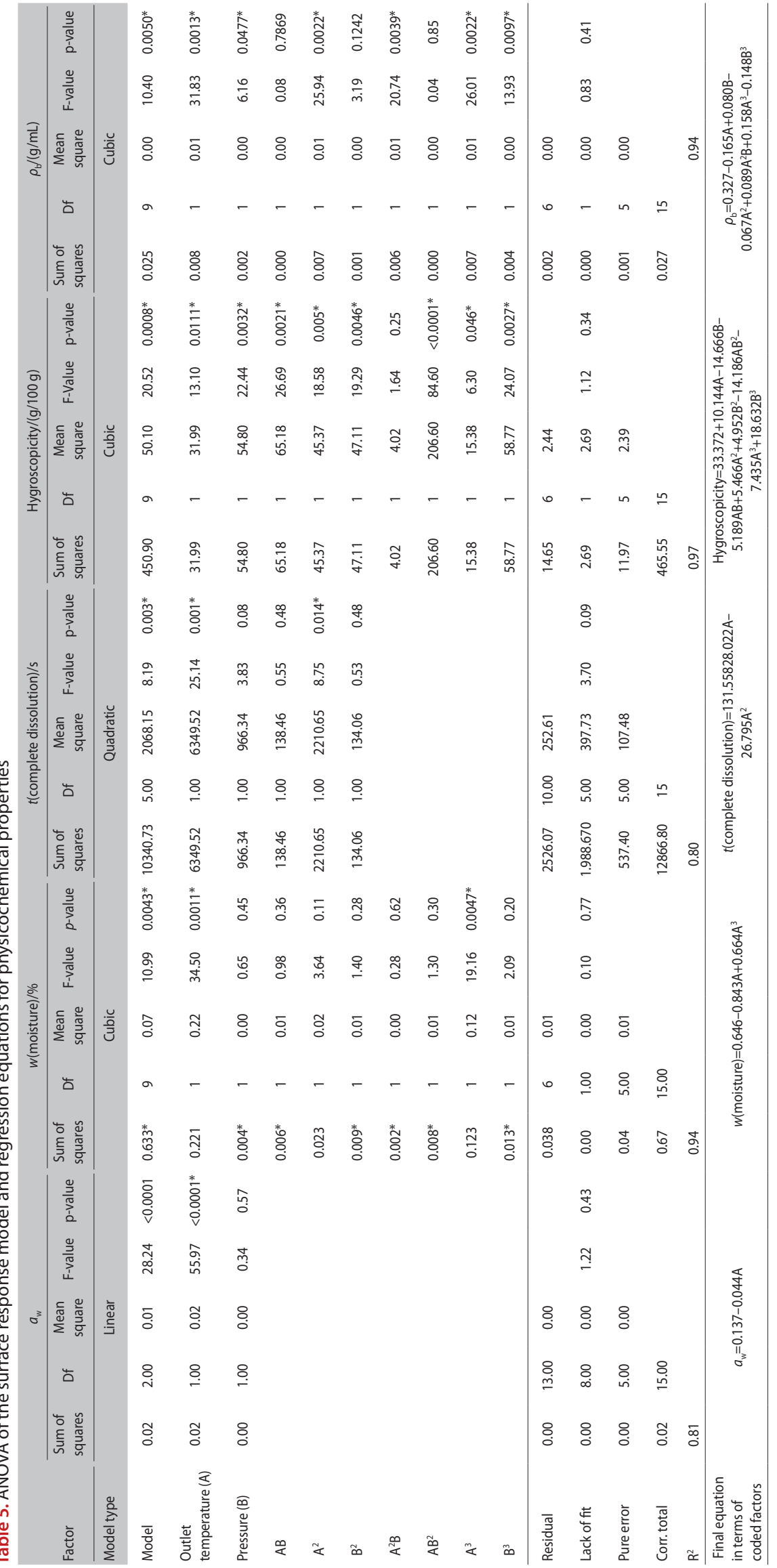


a)

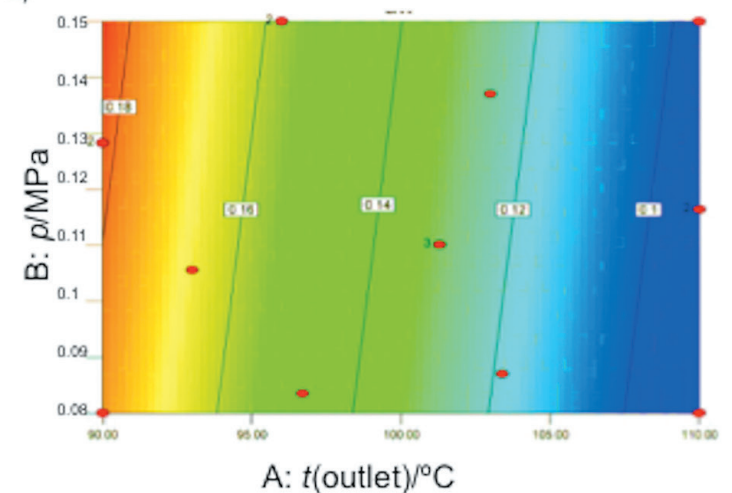

c)

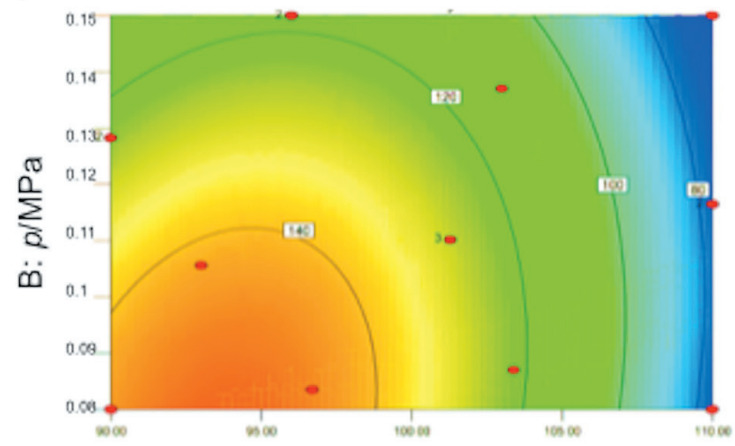

A: $t$ (outlet) $/^{\circ} \mathrm{C}$ b)

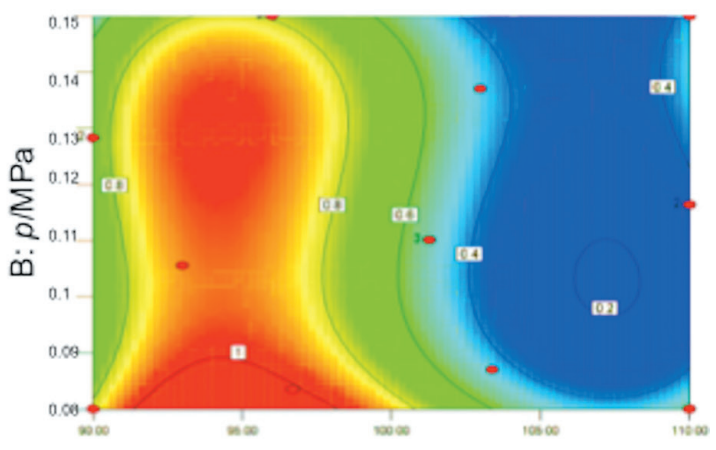

A: $t$ (outlet) $/{ }^{\circ} \mathrm{C}$

d)

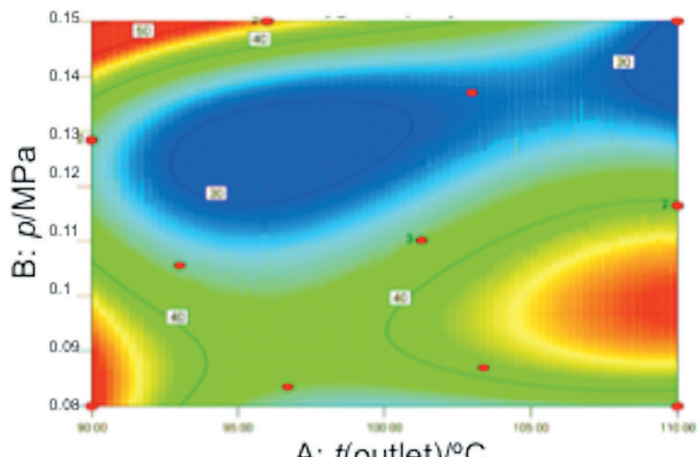

e)

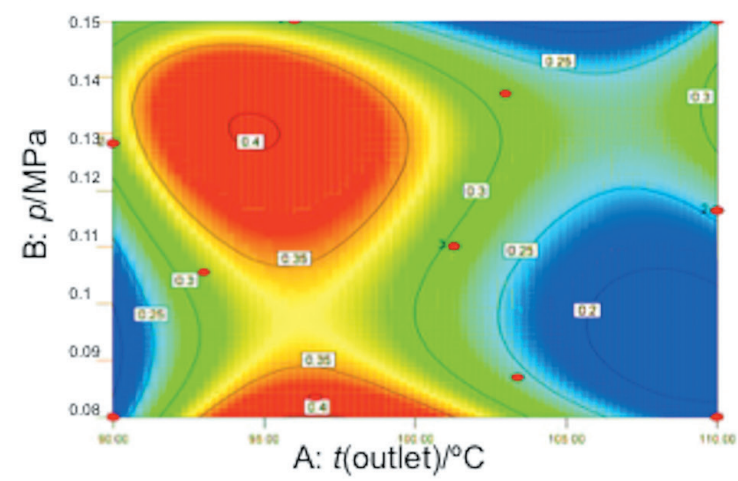

Fig. 4. Contour plots of: a) water activity, b) moisture content), c) time of complete dissolution, d) hygroscopicity, and e) bulk density

\section{Comparison of morphometric features}

ANOVA revealed no significant differences between the diameter and FDt values ( $p=0.761$ and 0.399 , respectively) (Table 2). The powder obtained under optimal drying conditions showed a spherical shape with few fractures and concavities on the surface (Fig. 3a), with a smoother surface than the culture medium powder. The culture medium powder had rougher particles (Fig. 3b). Adding maltodextrin decreases the roughness because the maltodextrin molecules join with denatured whey proteins, creating stronger steric hindrance against protein aggregation (69) and producing particles with a smoother surface, as observable in this study.
The diameter values of the optimized powder and culture medium powder were $(<13.7 \pm 0.3) \mu \mathrm{m}$ (Table 2$)$. In industrial production, capsule sizes below $100 \mu \mathrm{m}$ prevent gritty or sandy undesirable textural properties in the food product (63). Therefore, the powder product obtained in this study had the correct size for use in functional foods.

\section{Storage conditions}

Both powder obtained under optimal conditions and culture medium powder were evaluated at 4,25 and $37^{\circ} \mathrm{C}$ for 36 days to determine the cell count, moisture content and water activity. Fig. 5a shows L. fermentum K73 behaviour at 4, 25 
Table 6. Predicting shelf life time and specific rate of bacterial survival, change in moisture content and water activity of powders

\begin{tabular}{|c|c|c|c|c|c|c|c|c|c|c|c|c|c|c|}
\hline \multirow{3}{*}{ Temperature $/{ }^{\circ} \mathrm{C}$} & \multicolumn{7}{|c|}{ Culture medium powder } & \multicolumn{7}{|c|}{ Optimized powder } \\
\hline & \multicolumn{3}{|c|}{ Bacterial survival } & \multicolumn{2}{|c|}{$w($ moisture $) / \%$} & \multicolumn{2}{|c|}{$a_{\mathrm{w}}$} & \multicolumn{3}{|c|}{ Bacterial survival } & \multicolumn{2}{|c|}{$w($ moisture $) / \%$} & \multicolumn{2}{|c|}{$a_{\mathrm{w}}$} \\
\hline & $k_{\mathrm{m}} /$ day & $\mathrm{R}^{2}$ & $\begin{array}{c}\text { Shelf life/ } \\
\text { day }\end{array}$ & $k_{x} /$ day & $\mathrm{R}^{2}$ & $k_{\mathrm{w}} /$ day & $R^{2}$ & $k_{\mathrm{m}} /$ day & $R^{2}$ & $\begin{array}{c}\text { Shelf life/ } \\
\text { day }\end{array}$ & $k_{\mathrm{x}} /$ day & $\mathrm{R}^{2}$ & $k_{\mathrm{w}} /$ day & $\mathrm{R}^{2}$ \\
\hline 4 & -0.043 & 0.94 & 54.89 & 0.0106 & 0.95 & 0.0065 & 0.80 & -0.12 & 0.94 & 23.03 & 0.0084 & 0.84 & 0.0080 & 0.85 \\
\hline 25 & -0.039 & 0.84 & 57.51 & 0.0113 & 0.94 & 0.0087 & 0.94 & -0.39 & 0.88 & 7.66 & 0.0145 & 0.92 & 0.0101 & 0.88 \\
\hline 37 & -1.19 & 0.98 & 2.78 & 0.0160 & 0.91 & 0.0106 & 0.92 & -1.08 & 0.94 & 3.23 & 0.0163 & 0.95 & 0.0123 & 0.95 \\
\hline
\end{tabular}

$k_{\mathrm{m}}=$ specific viability loss $\left(\right.$ day $\left.^{-1}\right), k_{\mathrm{x}}=$ specific moisture content change rate $\left(\right.$ day $\left.^{-1}\right), k_{\mathrm{w}}=$ specific water activity change rate $\left(\right.$ day $\left.^{-1}\right)$

a)
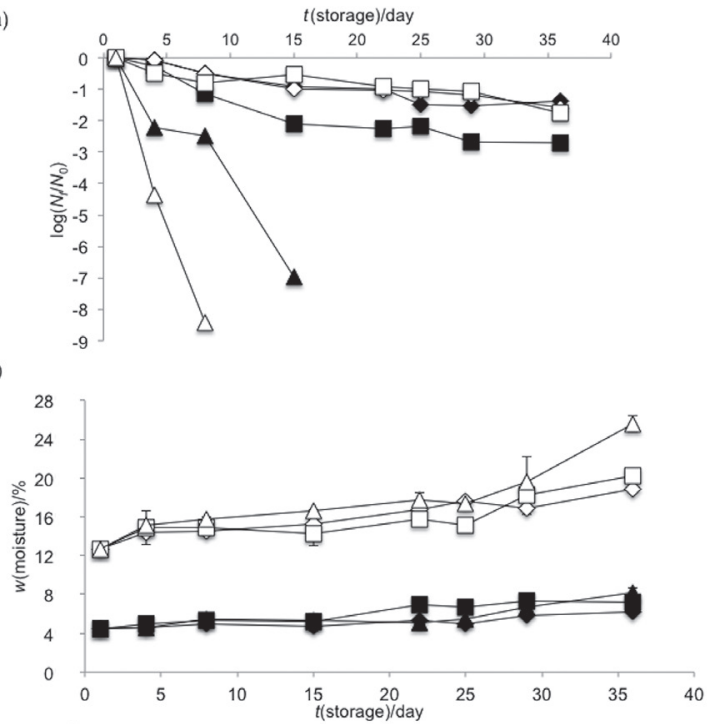

c) 0.40

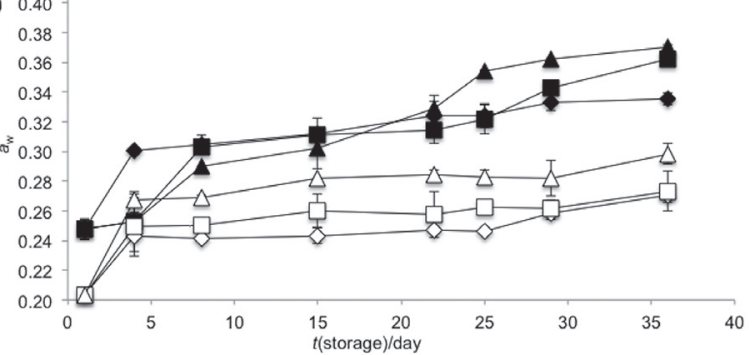

Fig. 5. Effect of the cryoprotective matrices on: a) the ratio of viability of bacteria at time $t$ and time zero $\left(\log \left(N_{t} / N_{0}\right)\right)$, b) moisture content, and c) water activity at $4{ }^{\circ} \mathrm{C}$ (diamond), $25^{\circ} \mathrm{C}$ (square) and $37^{\circ} \mathrm{C}$ (triangle). The cryoprotective matrices were culture medium (white shapes) and maltodextrin with whey (black shapes). The error bar corresponds to the mean values of triplicate measurements \pm S.D.

and $37{ }^{\circ} \mathrm{C}$ spray-dried with and without carrier material. The results showed that $k_{\mathrm{m}}, k_{\mathrm{x}}$ and $k_{\mathrm{w}}$ increased with increasing storage temperature and with the use of maltodextrin/sweet whey (0.61:0.39) (Table 6). The storage of powders showed the highest viability losses at $37^{\circ} \mathrm{C}$ (Fig. 5a), while lower $k_{\mathrm{m}}$ occurred at $4{ }^{\circ} \mathrm{C}$ (Table 6).

The viability of the microorganisms dried using culture medium as the carrier material was similar at 4 and $25^{\circ} \mathrm{C}$ (Fig. $5 a$ ) and showed similar $k_{m}$ values (Table 6), although the $k_{\mathrm{m} 25{ }^{\circ} \mathrm{C}}$ $=-0.04$ days $^{-1}$ was lower than $k_{\mathrm{m} 4{ }^{\circ} \mathrm{C}}=-0.04$ days $^{-1}$. Additionally, the predicted shelf life (Table 6) showed that the viability of microorganisms was better at $25^{\circ} \mathrm{C}$ (57.51 days) than at $4{ }^{\circ} \mathrm{C}$
(54.89 days). The observed increase in viability at $25^{\circ} \mathrm{C}$ may have been because the moisture content was high ((12.7 \pm 0.2$)$ $\%)$ in the culture medium capsules but stable during storage (Fig. 5b). This stability may help maintain L. fermentum K73 viability at $25^{\circ} \mathrm{C}$, as described above. The high moisture content may help microorganisms repair the injured areas on the cell membrane.

In contrast, the $k_{\mathrm{m}}$ values of the viability loss kinetics (Fig. 5a) of $L$. fermentum K73 with carrier material increased with storage temperature (Table 6). The moisture content of powder obtained under optimal conditions was low $(<8.2 \pm 0.5$, wet basis, Fig. $5 \mathrm{~b}$ ) and constant at all evaluated temperatures, while the $a_{\mathrm{w}}$ values were high $(<0.370 \pm 0.002)$, Fig. $5 \mathrm{c}$. Therefore, the viability loss and short shelf life $\left(23\right.$ days at $4{ }^{\circ} \mathrm{C}$, Table 6) may be attributed to the $a_{\mathrm{w}}$ values. It has been suggested that $a_{\mathrm{w}}$ values greater than 0.25 considerably increase the $k_{\mathrm{m}}$ of lactic acid bacteria, such as L. fermentum K73, likely by stimulating its metabolism that is affected by high molecular mobility in the carrier material (4).

Shelf life results showed that using culture medium as a carrier material protected $L$. fermentum $\mathrm{K} 73$ not only from the spray drying conditions, but also from the storage temperatures. The best conditions were at $25^{\circ} \mathrm{C}$, followed by those at $4{ }^{\circ} \mathrm{C}$. The moisture content may determine the viability of $L$. fermentum $\mathrm{K} 73$, but these data must be interpreted with caution. This may occur because of the repair of the damage to the cell membrane at high moisture content after drying, but further studies are needed to confirm this.

\section{CONCLUSIONS}

We evaluated the multifunctional roles of whey culture medium in the spray drying microencapsulation of Lactobacillus fermentum K73. The experimental design of the mixtures showed that the carrier materials are a source of substrate for the bacilli, but they also protect against in vitro simulated gastric conditions. The use of culture medium as part of the mixtures improved the physicochemical properties of the powders and increased the survival of the microorganisms under the evaluated conditions by decreasing the downstream processes. Complementarily, the optimal mixture of maltodextrin and sweet whey, spray-dried at an outlet temperature of $90.79^{\circ} \mathrm{C}$ and atomizing pressure of $0.117 \mathrm{MPa}$, maintained microorganism viability after drying and allowed them to survive under in vitro gastrointestinal conditions. Because the 
protein-carbohydrate complex maintained its glassy state on the microorganism membrane, exerting resistance to water migration, there were no large lesions on the cell membrane of $L$. fermentum K73. We assessed the physicochemical properties (water activity, moisture content, solubility, hygroscopicity and bulk density) and suitability of microcapsules produced under different drying conditions for inclusion in a food matrix. Therefore, future studies need to develop products that not only meet the regulatory cellular concentrations but also exert effects on consumer health.

Shelf life analysis revealed that the drying and storage temperatures are critical factors in bacterial survival. The use of culture medium as a carrier material improved the viability of $L$. fermentum $\mathrm{K} 73$ at $4{ }^{\circ} \mathrm{C}$, and thus, the probiotic product can be stored at refrigeration temperature for 87.4 days.

Our results showed that the culture medium is an effective carrier material because the microorganism survived after drying and under simulated gastrointestinal conditions, and the powder was stable during storage at 4 and $25^{\circ} \mathrm{C}$. The size and some physicochemical features are suitable for industrial requirements. Thus, our results can help develop additional one-step microencapsulation processes that optimize time and cost.

\section{ACKNOWLEDGEMENTS}

The Research Department of University of La Sabana, Colombia grant supported the study (ING 136-2013). The Colciencias National Doctoral scholarship 617-2 supported the doctoral student Stephania Aragón Rojas.

\section{REFERENCES}

1. Guidelines for the Evaluation of Probiotics in Food. Report of a joint FAO/WHO Working Groups on drafting guidelines for the evaluation of probiotics in food. London, Ontario, Canada. Geneva, Switzerland: Food and Agriculture Organization of the United Nations and Word Health Organization (FAO/WHO); 2002. pp. 1-11. Available from: http://www. who.int/foodsafety/fs_management/en/probiotic_guidelines.pdf.

2. Vitali B, Minervini G, Rizzello CG, Spisni E, Maccaferri S, Brigidi $\mathrm{P}$, et al. Novel probiotic candidates for humans isolated from raw fruits and vegetables. Food Microbiol. 2012;31(1): 116-25.

https://doi.org/10.1016/j.fm.2011.12.027

3. Cueto $C$, Aragón S. Evaluation of probiotic potential of lactic acid bacteria to reduce in vitro cholesterol. Sci Agropecu. 2012;3(1):45-50.

https://doi.org/10.17268/sci.agropecu.2012.01.06

4. Liao LK, Wei XY, Gong X, Li JH, Huang T, Xiong T. Microencapsulation of Lactobacillus casei LK-1 by spray drying related to its stability and in vitro digestion. LWT - Food Sci Technol. 2017;82:82-9.

https://doi.org/10.1016/j.lwt.2017.03.065
5. Arslan-Tontul S, Erbas M. Single and double layered microencapsulation of probiotics by spray drying and spray chilling. LWT - Food Sci Technol. 2017;81:160-9.

https://doi.org/10.1016/j.lwt.2017.03.060

6. Bulatović MLj, Krunić TŽ, Vukašinović-Sekulić MS, Zarić DB, Rakin MB. Quality attributes of a fermented whey-based beverage enriched with milk and a probiotic strain. RSC Adv. 2014;4(98):55503-10.

https://doi.org/10.1039/C4RA08905G

7. Muhammad Z, Ramzan R, Huo GC, Tian H, Bian X. Integration of polysaccharide-thermoprotectant formulations for microencapsulation of Lactobacillus plantarum, appraisal of survivability and physico-biochemical properties during storage of spray dried powders. Food Hydrocoll. 2017;66: 286-95.

https://doi.org/10.1016/j.foodhyd.2016.11.040

8. Eckert C, Serpa VG, Felipe dos Santos AC, Marinês da Costa S, Dalpubel V, Lehn DN, Volken de Souza CF. Microencapsulation of Lactobacillus plantarum ATCC 8014 through spray drying and using dairy whey as wall materials. LWT - Food Sci Technol. 2017;82:176-83.

https://doi.org/10.1016/j.lwt.2017.04.045

9. Dianawati D, Mishra V, Shah NP. Survival of microencapsulated probiotic bacteria after processing and during storage: A review. Crit Rev Food Sci Nutr. 2016;56(10):1685-716. https://doi.org/10.1080/10408398.2013.798779

10. Ferreira V, Soares V, Santos C, Silva J, Gibbs PA, Teixeira P. Survival of Lactobacillus sakei during heating, drying and storage in the dried state when growth has occurred in the presence of sucrose or monosodium glutamate. Biotechnol Lett. 2005;27(4):249-52.

https://doi.org/10.1007/s10529-004-8351-x

11. Ying D, Sun J, Sanguansri L, Weerakkody R, Augustin MA. Enhanced survival of spray-dried microencapsulated Lactobacillus rhamnosus GG in the presence of glucose. J Food Eng. 2012;109(3):597-602.

https://doi.org/10.1016/j.jfoodeng.2011.10.017

12. Agudelo J, Cano A, González-Martínez C, Chiralt A. Disaccharide incorporation to improve survival during storage of spray dried Lactobacillus rhamnosus in whey protein-maltodextrin carriers. J Funct Foods. 2017;37:416-23. https://doi.org/10.1016/j.jff.2017.08.014

13. Burgain J, Corgneau M, Scher J, Gaiani C. Encapsulation of probiotics in milk protein microcapsules. In: Sagis MCL, editor. Microencapsulation and microspheres for food applications. Cambridge, MA, USA: Elsevier; 2015. pp. 391-406. https://doi.org/10.1016/B978-0-12-800350-3.00019-4

14. Felix PHC, Birchal VS, Botrel DA, Marques GR, Borges SV. Physicochemical and thermal stability of microcapsules of cinnamon essential oil by spray drying. J Food Process Preserv. 2016;41(3):e12919.

https://doi.org/10.1111/jfpp.12919 
15. Nale Z, Tontul I, Aşçi Arslan A, Nadeem HS, Kucukcetin A. Microbial viability, physicochemical and sensory properties of kefir microcapsules prepared using maltodextrin/Arabic gum mixes. Int J Dairy Technol. 2017;71(S1):61-72.

https://doi.org/10.1111/1471-0307.12402

16. Nongonierma AB, FitzGerald RJ. Strategies for the discovery, identification and validation of milk protein-derived bioactive peptides. Trends Food Sci Technol. 2016;50:26-43. https://doi.org/10.1016/j.tifs.2016.01.022

17. Koutinas A, Papapostolou H, Dimitrellou D, Kopsahelis N, Katechaki E, Bekatorou A, Bosnea LA. Whey valorisation: A complete and novel technology development for dairy industry starter culture production. Bioresour Technol. 2009; 100(15):3734-9.

https://doi.org/10.1016/j.biortech.2009.01.058

18. Negrão-Murakami A, Nunes GL, Pinto SS, Murakami FS, Amante ER, Petrus JCC, et al. Influence of DE-value of maltodextrin on the physicochemical properties, antioxidant activity, and storage stability of spray dried concentrated mate (Ilex paraguariensis A. St. Hil.). LWT - Food Sci Technol. 2017;79:561-7.

https://doi.org/10.1016/j.lwt.2016.11.002

19. Desmond C, Ross RP, O'Callaghan E, Fitzgerald G, Stanton C. Improved survival of Lactobacillus paracasei NFBC 338 in spray-dried powders containing gum acacia. J Appl Microbiol. 2002;93(6):1003-11.

https://doi.org/10.1046/j.1365-2672.2002.01782.x

20. Salavati Schmitz S, Allenspach K. Effects of different oligosaccharides on growth of selected probiotic bacterial strains. J Microb Biochem Technol. 2017;9(2):572-6.

https://doi.org/10.4172/1948-5948.1000343

21. Rajam R, Anandharamakrishnan C. Microencapsulation of Lactobacillus plantarum (MTCC 5422) with fructooligosaccharide as wall material by spray drying. LWT - Food Sci Technol. 2015;60(2, Pt 1):773-80.

https://doi.org/10.1016/j.lwt.2014.09.062

22. Salar-Behzadi S, Wu S, Toegel S, Hofrichter M, Altenburger I, Unger FM, et al. Impact of heat treatment and spray drying on cellular properties and culturability of Bifidobacterium bifidum BB-12. Food Res Int. 2013;54(1):93-101.

https://doi.org/10.1016/j.foodres.2013.05.024

23. Champagne $C P$, Ross RP, Saarela M, Flemming Hansen $K$, Charalampopoulos D. Recommendations for the viability assessment of probiotics as concentrated cultures and in food matrices. Int J Food Microbiol. 2011;149(3):185-93. https://doi.org/10.1016/j.jfoodmicro.2011.07.005

24. Song H, Yu W, Gao M, Liu X, Ma X. Microencapsulated probiotics using emulsification technique coupled with internal or external gelation process. Carbohydr Polym. 2013;96(1): $181-9$.

https://doi.org/10.1016/j.carbpol.2013.03.068

25. Dimitrellou D, Kandylis P, Petrović T, Dimitrijević-Branković S, Lević S, Nedović V, Kourkoutas Y. Survival of spray dried microencapsulated Lactobacillus casei ATCC 393 in simulated gastrointestinal conditions and fermented milk. LWT - Food Sci Technol. 2016;71:169-74.

https://doi.org/10.1016/j.lwt.2016.03.007

26. Cueto-Vigil MC, Acuña-Monsalve Y, Valenzuela-Riaño J. In vitro of probiotic potential of lactic acid bacteria isolated from coastal serum. Actu Biol. 2010;32(93):129-38.

27. Anandharamakrishnan C, Rielly CD, Stapley AGF. Effects of process variables on the denaturation of whey proteins during spray drying. Dry Technol. 2007;25(5):799-807. https://doi.org/10.1080/07373930701370175

28. Design Expert, v. 8.0.7.1, Stat-Ease Inc., Minneapolis, MN, USA; 2010.

29. Behboudi-Jobbehdar S, Soukoulis C, Yonekura L, Fisk I. Optimization of spray-drying process conditions for the production of maximally viable microencapsulated L. acidophilus NCIMB 701748. Dry Technol. 2013;31(11):1274-83.

https://doi.org/10.1080/07373937.2013.788509

30. Henao-Ardila A, Quintanilla-Carvajal MX, Klotz-Ceberio BF, Serna-Jiménez JA. Evaluation of inhibition of the Candida intermedia due to the effect of supernatants from bioprotector and their synergistics effect. Rev Mex Ing Química. 2015;14(2):373-81.

31. Jeong IJ, Kim KJ. An interactive desirability function method to multiresponse optimization. Eur J Oper Res. 2009; 195(2):412-26.

https://doi.org/10.1016/j.ejor.2008.02.018

32. Harris RF, Sommers LE. Plate-dilution frequency technique for assay of microbial ecology. Appl Microbiol. 1968;16(2): 330-4.

33. Guo XH, Kim JM, Nam HM, Park SY, Kim JM. Screening lactic acid bacteria from swine origins for multistrain probiotics based on in vitro functional properties. Anaerobe. 2010; 16(4):321-6.

https://doi.org/10.1016/j.anaerobe.2010.03.006

34. Lin WH, Hwang CF, Chen LW, Tsen HY. Viable counts, characteristic evaluation for commercial lactic acid bacteria products. Food Microbiol. 2006;23(1):74-81. https://doi.org/10.1016/j.fm.2005.01.013

35. Gbassi GK, VandammeT. Probiotic encapsulation technology: from microencapsulation to release into the gut. Pharmaceutics. 2012;4(1):149-63.

https://doi.org/10.3390/pharmaceutics4010149

36. Official methods of analysis of AOAC international. Rockville, MD, USA: AOAC International; 2006.

37. Fritzen-Freire CB, Prudêncio ES, Pinto SS, Muñoz IB, Amboni RDMC. Effect of microencapsulation on survival of Bifidobacterium BB-12 exposed to simulated gastrointestinal conditions and heat treatments. LWT - Food Sci Technol. 2013;50(1):39-44.

https://doi.org/10.1016/j.lwt.2012.07.037

38. Pinto SS, Fritzen-Freire CB, Benedetti S, Murakami FS, Petrus JCC, Prudêncio ES, Amboni RDMC. Potential use of whey 
concentrate and prebiotics as carrier agents to protect Bifidobacterium-BB-12 microencapsulated by spray drying. Food Res Int. 2015;67:400-8.

https://doi.org/10.1016/j.foodres.2014.11.038

39. Caparino OA, Tang J, Nindo Cl, Sablani SS, Powers JR, Fellman JK. Effect of drying methods on the physical properties and microstructures of mango (Philippine "Carabao" var.) powder. J Food Eng. 2012;111(1):135-48. https://doi.org/10.1016/j.jfoodeng.2012.01.010

40. Hernández-Carrión M, Hernando I, Sotelo-Díaz I, Quintanilla-Carvajal MX, Quiles A. Use of image analysis to evaluate the effect of high hydrostatic pressure and pasteurization as preservation treatments on the microstructure of red sweet pepper. Innov Food Sci Emerg Technol. 2015;27:69-78.

https://doi.org/10.1016/j.ifset.2014.10.011

41. Quintanilla-Carvajal MX, Meraz-Torres LS, Alamilla-Beltrán L, Chanona-Pérez JJ, Terres-Rojas E, Hernández-Sánchez H, et al. Morphometric characterization of spray-dried microcapsules before and after a-tocopherol extraction. Rev Mex Ing Química. 2011;10(2):301-12.

42. Schneider CA, Rasband WS, Eliceiri KW. NIH Image to Image J: 25 years of image analysis. Nat Methods. 2012;9:671-5.

43. Yonekura L, Sun H, Soukoulis C, Fisk I. Microencapsulation of Lactobacillus acidophilus NCIMB 701748 in matrices containing soluble fibre by spray drying:Technological characterization, storage stability and survival after in vitro digestion. J Funct Foods. 2014;6: 205-14.

https://doi.org/10.1016/j.jff.2013.10.008

44. González-Ferrero C, Irache JM, González-Navarro CJ. Soybean protein-based microparticles for oral delivery of probiotics with improved stability during storage and gut resistance. Food Chem. 2018;239:879-88.

https://doi.org/10.1016/j.foodchem.2017.07.022

45. Tsironi T, Dermesonlouoglou E, Giannoglou M, Gogou E, Katsaros G, Taoukis P. Shelf-life prediction models for ready-to-eat fresh cut salads: Testing in real cold chain. Int J Food Microbiol. 2017;240:131-40.

https://doi.org/10.1016/j.ijfoodmicro.2016.09.032

46. Klindt-Toldam S, Larsen SK, Saaby L, Olsen LR, Svenstrup G, Müllertz A, et al. Survival of Lactobacillus acidophilus NCFM ${ }^{\circledR}$ and Bifidobacterium lactis HN019 encapsulated in chocolate during in vitro simulated passage of the upper gastrointestinal tract. LWT - Food Sci Technol. 2016; 74:404-10. https://doi.org/10.1016/j.lwt.2016.07.053

47. Fu N, Chen XD. Towards a maximal cell survival in convective thermal drying processes. Food Res Int. 2011;44(5): 1127-49. https://doi.org/10.1016/j.foodres.2011.03.053

48. Zheng X, Fu N, Huang S, Jeantet R, Chen XD. Exploring the protective effects of calcium-containing carrier against drying-induced cellular injuries of probiotics using single droplet drying technique. Food Res Int. 2016;90:226-34. https://doi.org/10.1016/j.foodres.2016.10.034
49. Seth D, Mishra HN, Deka SC. Effect of microencapsulation using extrusion technique on viability of bacterial cells during spray drying of sweetened yoghurt. Int J Biol Macromol. 2017;103:802-7.

https://doi.org/10.1016/j.jibiomac.2017.05.099

50. Agyei D, Ongkudon CM, Wei CY, Chan AS, Danquah MK. Bioprocess challenges to the isolation and purification of bioactive peptides. Food Bioprod Process. 2016;98:244-56. https://doi.org/10.1016/j.fbp.2016.02.003

51. Ying D, Schwander S, Weerakkody R, Sanguansri L, Gantenbein-Demarchi C, Augustin MA. Microencapsulated Lactobacillus rhamnosus GG in whey protein and resistant starch matrices: Probiotic survival in fruit juice. J Funct Foods. 2013;5(1):98-105.

https://doi.org/10.1016/j.jff.2012.08.009

52. Liong MT, Shah NE. Optimization of growth of Lactobacillus casei ASCC 292 and production of organic acids in the presence of fructooligosaccharide and maltodextrin. J Food Sci. 2005;70(2):M113-20.

https://doi.org/10.1111/j.1365-2621.2005.tb07100.x

53. Olano-Martin E, Mountzouris KC, Gibson GR, Rastall RA. In vitro fermentability of dextran, oligodextran and maltodextrin by human gut bacteria. Br J Nutr. 2000;83(3):247-55. https://doi.org/10.1017/S0007114500000325

54. Cherbut C, Michel C, Raison V, Kravtchenko T, Severine M. Acacia gum is a bifidogenic dietary fibre with high digestive tolerance in healthy humans. Microb Ecol Health Dis. 2003;15(1):43-50.

https://doi.org/10.1080/08910600310014377

55. Zhu SC, Ying DY, Sanguansri L, Tang JW, Augustin MA. Both stereo-isomers of glucose enhance the survival rate of microencapsulated Lactobacillus rhamnosus GG during storage in the dry state. J Food Eng. 2013;116(4):809-13.

https://doi.org/10.1016/j.jfoodeng.2013.01.028

56. Kumar R, Grover S, Batish VK. Hypocholesterolaemic effect of dietary inclusion of two putative probiotic bile salt hydrolase-producing Lactobacillus plantarum strains in Sprague-Dawley rats. Br J Nutr. 2011;105(4):561-73.

https://doi.org/10.1017/S0007114510003740

57. Garre E, Raginel F, Palacios A, Julien A, Matallana E. Oxidative stress responses and lipid peroxidation damage are induced during dehydration in the production of dry active wine yeasts. Int J Food Microbiol. 2010;136(3):295-303. https://doi.org/10.1016/j.ijfoodmicro.2009.10.018

58. Bustos P, Bórquez R. Influence of osmotic stress and encapsulating materials on the stability of autochthonous Lactobacillus plantarum after spray drying. Dry Technol. 2013; 31(1):57-66.

https://doi.org/10.1080/07373937.2012.717325

59. Huang S, Rabah H, Jardin J, Briard-Bion V, Parayre S, Maillard MB, et al. Hyperconcentrated sweet whey, a new culture medium that enhances Propionibacterium 
freudenreichii stress tolerance. Appl Environ Microbiol. 2016; 82(15):4641-51.

https://doi.org/10.1128/AEM.00748-16

60. Haque MA, Aldred P, Chen J, Barrow CJ, Adhikari B. Comparative study of denaturation of whey protein isolate (WPI) in convective air drying and isothermal heat treatment processes. Food Chem. 2013;141(2):702-11. https://doi.org/10.1016/j.foodchem.2013.03.035

61. Chandrapala J, Duke MC, Gray SR, Zisu B, Weeks M, Palmer $M$, Vasiljevic T. Properties of acid whey as a function of $\mathrm{pH}$ and temperature. J Dairy Sci. 2015;98(7):4352-63. https://doi.org/10.3168/jds.2015-9435

62. Ying DY, Phoon MC, Sanguansri L, Weerakkody R, Burgar I, Augustin MA. Microencapsulated Lactobacillus rhamnosus GG powders: Relationship of powder physical properties to probiotic survival during storage. J Food Sci. 2010;75(9): E588-95.

https://doi.org/10.1111/j.1750-3841.2010.01838.x

63. Çabuk B, Harsa TS. Micro and nano carriers Improved viability of Lactobacillus acidophilus NRRL-B 4495 during freeze-drying in whey protein-pullulan microcapsules. J Microencapsul. 2015;32(3):300-7.

https://doi.org/10.3109/02652048.2015.1017618

64. Tompkins TA, Mainville I, Arcand Y. The impact of meals on a probiotic during transit through a model of the human upper gastrointestinal tract. Benef Microbes. 2011;2(4): 295-303.

https://doi.org/10.3920/BM2011.0022
65. Finney J, Buffo R, Reineccius GA. Effects of type of atomization and processing temperatures on the physical properties and stability of spray-dried flavors. J Food Sci. 2002; 67:1108-14.

https://doi.org/10.1111/j.1365-2621.2002.tb09461.x

66. Jiménez M, Flores-Andrade E, Pascual-Pineda LA, Beristain $\mathrm{Cl}$. Effect of water activity on the stability of Lactobacillus paracasei capsules. LWT - Food Sci Technol. 2015; 60(1):346-51.

https://doi.org/10.1016/j.Iwt.2014.09.050

67. Lira de Medeiros AC, Thomazini M, Urbano A, Pinto Correia RT, Favaro-Trindade CS. Structural characterisation and cell viability of a spray dried probiotic yoghurt produced with goats' milk and Bifidobacteriu m animalis subsp. lactis (BI-07). Int Dairy J. 2014;39(1):71-7. https://doi.org/10.1016/j.idairyj.2014.05.008

68. Tonon RV, Brabet C, Hubinger MD. Influence of process conditions on the physicochemical properties of açai (Euterpe oleraceae Mart.) powder produced by spray drying. J Food Eng. 2008;88(3):411-8.

https://doi.org/10.1016/j.jfoodeng.2008.02.029

69. Wang W, Zhong Q. Properties of whey protein-maltodextrin conjugates as impacted by powder acidity during the Maillard reaction. Food Hydrocoll. 2014;38:85-94. https://doi.org/10.1016/j.foodhyd.2013.11.018 